\title{
PENERAPAN PROBLEM BASED LEARNING PADA PEMBELAJARAN KONSEP HIDROLISI GARAM UNTUK MENINGKATKAN HASIL BELAJAR SISWA
}

\author{
Restu Desriyanti $^{1}$, Lazulva $^{2}$ \\ 1 Program Studi Pendidikan Kimia, Fakultas Tarbiyah dan Keguruan, UIN Suska Riau, \\ Jl. H. R. Soebrantas Km. 15 Tampan Pekanbaru Riau 28293, Indonesia \\ e-mail: raja.restu23@gmail.com
}

\begin{abstract}
ABSTRAK
Penelitian ini dilatarbelakangi dengan rendahnya hasil belajar kimia siswa kelas XI pada materi hidrolisis garam. Untuk itu, dilaksanakan penelitian eksperimen dengan rancangan pretest dan postest untuk mengetahui pengaruh penerapan model Problem Based Learning terhadap hasil belajar siswa kelas XI SMA Negeri 4 Pekanbaru pada materi hidrolisis garam. Subjek penelitian ini adalah siswa kelas XI IPA tahun ajaran 2014/2015 dengan jumlah sampel 2 kelas yaitu XI IPA 1 (eksperimen) dan XI IPA 4 (kontrol). Data penelitian dikumpulkan melalui observasi, tes data awal yaitu tes homogenitas dan tes data akhir yaitu pretest dan postest, serta dokumentasi. Untuk mengetahui pengaruh penerapan model terhadap hasil belajar digunakan rumus Kp. Perbedaan pengaruh dianalisis dengan t-test sampel related. Hasil analisis data awal dan data akhir diperoleh nilai $t_{\text {hitung }}=2,55$ dan $t_{\text {tabel }}=2,00$ pada taraf signifikan $5 \%$. Nilai $t_{\text {hitung }}>$ $t_{\text {tabel, }}$ sehingga $H_{o}$ ditolak, dan $H_{a}$ diterima yang berarti menunjukkan adanya pengaruh penerapan model Problem Based Learning terhadap hasil belajar siswa kelas XI SMA Negeri 4 Pekanbaru pada materi hidrolisis garam, dengan pengaruh sebesar $9,35 \%$.
\end{abstract}

Kata kunci: Hasil Belajar, Problem Based Learning, Hidrolisis garam.

\begin{abstract}
This research was motivated by the low of chemistry learning outcomes of students eleventh grade on salt hydrolysis topics. It was an out experimental research with pretest and post-test to identify the effect of the application problem based learning model on student learning outcomes of students at class XI SMAN 4 Pekanbaru on salt hydrolysis topics. The subjects of this research were students of class XI IPA 2014/2015 academic year with sample consists of two classes, they were: XI IPA 1 (experimental) and XI IPA 4 (control). The data were collected through observation, test, and documentation. To determine the effect of application model on the students learning outcomes used formula $\mathrm{Kp}$. The different of influence were analyzed by sample related $t$-test. The result of analyzed first and last data was $t_{\text {count }}=2.55$ and $t_{\text {table }}=2.00$ in $5 \%$ significance level, $H_{0}$ was rejected, and $H_{a}$ wasreceived. Because the $t_{\text {count }}>t_{\text {table }}$ which means indicates that there was an effect of application problem based learning model on students learning outcomes of class XI SMAN 4 Pekanbaru in the topic of salt hydrolysis which influence was 9.35\%.
\end{abstract}

Keywords: Learning Outcome, Problem Based Learning, Salt Hydrolysis.

DOI: http://dx.doi.org/10.15575/jta.v1i2.1236 


\section{PENDAHULUAN}

Pendidikan merupakan suatu hal yang sangat penting dalam kehidupan. Melalui proses pendidikan siswa akan dididik dan dibentuk sesuai dengan keahliannya. Pendidikan dikatakan berhasil apabila tujuan pendidikan dapat tercapai. Tujuan pendidikan adalah merubah pola pikir dari siswa serta menanamkan akhlak mulia kepada diri siswa tersebut. Untuk mencapai tujuan tersebut dibutuhkan suatu proses, yaitu proses pembelajaran.

Menurut Permendikbud 81 A kegiatan pembelajaran merupakan proses pendidikan yang memberikan kesempatan kepada siswa untuk mengembangkan potensi mereka menjadi kemampuan yang semakin lama dirinya untuk hidup dan untuk bermasyarakat, berbangsa serta berkontribusi pada kesejahteraan hidup umat manusia. Kegiatan pembelajaran perlu menggunakan prinsip yang: (1) berpusat pada siswa, mengembangkan kreativitas siswa, (3) menciptakan kondisi menyenangkan dan menantang, (4) bermuatan nilai, etika, estetika, logika, dan kinestetika, dan (5) menyediakan pengalaman belajar yang beragam melalui penerapan berbagai strategi dan metode pembelajaran yang menyenangkan, kontekstual, efektif, efisien, dan bermakna [1].

Salah satu masalah yang di hadapi dalam dunia pendidikan kita adalah masalah lemahnya proses pembelajaran [2]. Lemahnya proses pembelajaran mengakibatkan kurangnya pemahaman siswa terhadap pelajaran. Guru menyajikan materi dari awal hingga akhir. Siswa hanya menerima pengetahuan dari apa yang guru berikan. Siswa tidak diberi pengalaman dan kesempatan dalam pembelajaran untuk memperoleh pengetahuan itu sendiri. Kegiatan pembelajaran masih bersifat mendengarkan dan menghafal, bukan membangun pengetahuan, dengan demikian siswa tidak mampu membangun kerangka berpikirnya dan tidak mampu mengembangkan potensi yang dimilikinya.[3] Hal ini dibuktikan dengan rendahnya hasil belajar siswa di Sekolah Menengah Atas Negeri 4 Pekanbaru, yaitu: (1) Ulangan harian materi asam dan basa sebanyak $84,38 \%$ siswa memiliki nilai dibawah kriteria ketuntasan minimum (KKM) (2) Ulangan harian materi larutan penyangga sebanyak $81,25 \%$ siswa yang memiliki nilai dibawah KKM (3) Ulangan harian materi hidrolisis garam sebanyak $54,69 \%$ siswa memiliki nilai dibawah KKM (4) Ulangan harian materi hasil kali kelarutan sebanyak 70,03\% siswa memiliki nilai dibawah KKM (5) Ulangan harian materi koloid sebanyak 43,75\% siswa memiliki nilai dibawah KKM.

Berkaitan dengan masalah di atas untuk menciptakan proses pembelajaran yang mampu membangun kerangka berpikir siswa dan menyediakan pengalaman belajar kepada siswa sehingga siswa terlibat langsung dalam pembelajaran dapat digunakan model Problem Based Learning. Problem Based Learning adalah model pembelajaran berbasis masalah yang dirancang agar siswa mendapat pengetahuan penting yang membuat mereka mahir dalam memecahkan masalah dan memiliki kecakapan dalam berpartisipasi dalam tim. Pembelajaran berbasis masalah dikembangkan untuk membantu siswa mengembangkan kemampuan berpikir, pemecahan masalah, dan keterampilan intelektual. Belajar berbagai peran orang dewasa melalui pelibatan mereka dalam pengalaman nyata atau simulasi dan pembelajaran yang otonom dan mandiri [5]. Siswa memecahkan masalah yang ada 
bersama, sehingga akan meningkatkan pemahaman dan membangun kerangka berpikir dari siswa itu sendiri daripada hanya mendengarkan atau menerima materi secara keseluruhan dari guru. Model pembelajaran Problem Based Learning mengajarkan siswa bahwa informasi bisa berasal dari mana saja, kapan saja, tidak bergantung pada informasi searah dari guru. Siswa dituntut untuk mencari tahu dari berbagai sumber melalui penyelidikan, dan bukan hanya diberi tahu.

Keunggulan strategi pembelajaran berdasarkan masalah adalah sebagai berikut: (1) Pemecahan masalah merupakan teknik yang bagus untuk memahami isi pembelajaran, (2) Pemecahan masalah dapat merangsang kemampuan siswa untuk menemukan pengetahuan baru bagi mereka, (3) Pemecahan masalah dapat meningkatkan aktivitas belajar siswa, (4) Pemecahan masalah dapat membantu siswa untuk menerapkan pengetahuan mereka dalam kehidupan sehari-hari, (5) Pemecahan masalah dapat membantu siswa mengembangkan pengetahuannya serta dapat digunakan sebagai evaluasi diri terhadap hasil maupun proses belajar, (6) Pemecahan masalah dapat membantu siswa untuk berlatih berfikir dalam menghadapi sesuatu, (7) Pemecahan masalah dianggap menyenangkan dan lebih digemari siswa, (8) Pemecahan masalah mengembangkan keterampilan berpikir kritis dan kemampuan menyesuaikan dengan pengetahuan baru [2].

Tujuan utama PBL bukanlah penyampaian sejumlah besar ilmu pengetahuan kepada siswa, melainkan pada pengembangan kemampuan berpikir kritis dan kemampuan pemecahan masalah dan sekaligus mengembangkan kemampuan siswa untuk secara aktif membangun pengetahuan sendiri. PBL juga dimaksudkan untuk mengembangkan kemandirian belajar dan keterampilan sosial siswa. Kemandirian belajar dan keterampilan sosial itu dapat terbentuk ketika siswa berkolaborasi untuk mengidentifikasi informasi, strategi dan sumber belajar yang relevan untuk menyelesaikan masalah [4].

Sebagaimana Penelitian Aji Trihatmo, Soeprodjo dan Antonius tahun 2011 jurusan kimia FMIPA bahwa model problem based learning berpengaruh terhadap hasil belajar siswa dengan kontribusi sebesar 33,69\%. Kelas eksperimen memiliki presentase ketuntasan belajar klasikal 93,8\% dan kontrol 85\%. Aspek psikomotorik siswa pada kelas eksperimen $81,98 \%$ sedangkan kelas kontrol $79,31 \%$. Secara umum hasil belajar siswa kelas eksperimen lebih baik daripada siswa kelas kontrol [6]. Penelitian Penelitian Ratna Rosidah, Tri, dan Sri Retno tahun 2013 prodi Pendidikan Kimia UNS Surakarta dengan judul "Penerapan Model Problem Based Learning pada Pembelajaran Hukum Hukum Dasar Kimia Ditinjau dari Aktivitas dan Hasil Belajar Siswa Kelas X IPA SMA Negeri 2 Surakarta Tahun Pelajaran 2013/2014." Penelitian ini menunjukkan bahwa model PBL dilengkapi LKS dalam penerapan kurikulum 2013 dikategorikan baik dengan nilai rata-rata 82,71 dengan presentase ketercapaian 81,25\% [7].

Berdasarkan permasalahan yang ditemukan di SMA Negeri 4 Pekanbaru, maka penulis tertarik untuk melakukan penelitian yang berjudul "Pengaruh Penerapan Model Problem Based Learning Terhadap Hasil Belajar Siswa SMA Negeri 4 Pekanbaru." Jika terdapat pengaruh maka perlu diterapkan pendekatan dan model pembelajaran ini 
untuk tahun ajaran berikutnya sehingga dapat diperoleh hasil belajar yang lebih baik.

\section{METODE PENELITIAN}

Metode penelitian yang digunakan adalah metode quasy eksperimen. Quasy eksperimen dapat digunakan minimal kalau dapat mengontrol satu variabel saja [8]. Dalam hal ini peneliti menggunakan dua kelas dengan kemampuan yang sama dimana ada kelas kontrol dan kelas eksperimen. Kelas eksperimen adalah kelas yang diberi perlakuan menggunakan model Problem Based Learning dan kelas kontrol dengan metode ceramah. Kedua kelas tersebut sebelum diberi perlakuan terlebih dahulu diberi pretest untuk mengetahui sejauh mana materi yang akan diajarkan telah dapat dikuasai oleh siswa.

Populasi dalam penelitian ini adalah siswa kelas XI IPA 1, XI IPA 2 dan XI IPA 4 SMA Negeri 4 Pekanbaru semester genap tahun ajaran 2014/2015 yang berjumlah 96 orang. Sampel dalam penelitian ini adalah dua kelas XI IPA yang mempunyai tingkat homogenitas yang hampir sama. Satu kelas sebagai kelas kontrol dan satu kelas sebagai kelas eksperimen. Pengambilan sampel ini menggunakan teknik probability sampling, yaitu simple random sampling, karena pengambilan anggota sampel dari populasi dilakukan secara acak tanpa memperhatikan strata yang ada dalam populasi tersebut [9].

Teknik yang digunakan untuk mengumpulkan data dalam penelitian ini adalah observasi, tes (tes data awal dan tes data akhir) dan dokumentasi. Tes adalah instrumen yang digunakan untuk mengukur hasil belajar siswa. Tes yang dilakukan adalah uji homogenitas, pretest dan postest. Uji homogenitas dilakukan untuk mengetahui kesamaan kemampuan dasar yang dimiliki oleh populasi yang diuji. Soal yang diberikan adalah soal yang menjadi dasar dari materi hidrolisis garam, yaitu materi asam dan basa sebanyak 20 soal. Uji pretest dilakukan sebelum materi hidrolisis garam diajarkan dengan tujuan untuk mengetahui pengetahuan awal siswa terhadap materi yang akan diajarkan. Postest diberikan setelah materi hidrolisis garam diajarkan. Postest bertujuan untuk mengetahui seberapa besar kepemahaman siswa terhadap materi yang telah diajarkan.

Tes yang digunakan dalam penelitian harus valid, Oleh karena itu soal yang digunakan untuk mengukur hasil belajar terlebih dahulu harus diuji cobakan kelayakannya pada siswa kelas XII IPA dan kemudian dianalisis. Analisis soal meliputi analisis validitas soal (validitas isi), reliabilitas, daya pembeda, dan tingkat kesukaran soal. Analisis data akhir meliputi uji prasyarat (uji homogenitas dan uji normalitas) dan uji t. Untuk menentukan pengaruh dari model yang diterapkan digunakan rumus $\mathrm{Kp}$.

\section{HASIL DAN PEMBAHASAN}

Penelitian ini merupakan penelitian quasy eksperimen, sehingga dibutuhkan dua kelas dalam penelitian ini. Satu kelas sebagai kelas kontrol dan satu kelas sebagai kelas eksperimen. Kelas eksperimen diterapkan model Problem Based Learning sedangkan kelas kontrol dengan metode ceramah. Untuk mengetahui terdapat pengaruh atau tidak terhadap model yang diterapkan terlebih dahulu harus memilih kelas yang mempunyai kemampuan yang hampir sama atau homogen. Jadi, diharapkan pengaruh yang terjadi bukan karena perbedaan kemampuan dari siswa tapi 
karena model Problem Based Learning yang diterapkan. Oleh karena itu, perlu dilakukan uji homogenitas terlebih dahulu. Uji homogenitas dilakukan kepada 3 kelas, yaitu XI IPA 1, XI IPA 2, dan XI IPA 4 dengan materi yang menjadi dasar dari pelajaran hidrolisis yaitu asam dan basa. Soal yang diberikan merupakan soal pilihan ganda sebanyak 20 soal.

Soal yang sudah dikerjakan oleh siswa kemudian dianalisis dengan menggunakan uji bartlet untuk melihat tingkat kehomogenan dari ketiga kelas yang diuji. Jika nilai $\boldsymbol{x}^{2}$ hitung $<\boldsymbol{x}^{2}$ tabel maka dianggap varians-varians tersebut homogen. Nilai $\boldsymbol{x}^{2}$ hitung diperoleh sebesar 5,562, sedangkan $\boldsymbol{x}^{2}$ tabel sebesar 5,991. Nilai $\boldsymbol{x}^{2}$ hitung $<\boldsymbol{x}^{2}$ tabel sehingga dapat dianggap kelas XI IPA 1, XI IPA 2 dan XI IPA 4 mempunyai kemampuan yang homogen. Kelas eksperimen dan kelas kontrol dipilih acak dengan bantuan rekomendasi dari guru mata pelajaran kimia. Kelas XI IPA 1 dipilih sebagai kelas eksperimen dan diterapkan model Problem Based Learning sedangkan XI IPA 4 sebagai kelas kontrol yang menggunakan metode ceramah.

Hipotesis dalam penelitian ini diuji dengan selisih nilai pretest dengan postest. Nilai rata-rata pretest kelas eksperimen dan kelas kontrol memiliki perbandingan yang tergolong rendah. Kelas eksperimen memiliki nilai rata-rata sebesar 26,72 dan pada kelas kontrol memiliki nilai rata-rata 30,606 . Nilai pretest ini merupakan nilai rata-rata ketika siswa belum memasuki materi hidrolisis garam. Siswa masih belum banyak mengetahui tentang materi hidrolisis garam. Siswa masih bingung karena belum mempelajari materi yang diberikan, mereka mengisi jawaban hanya sebatas pengetahuan yang mereka ketahui serta pengalaman mereka dalam kehidupan sehari-hari. Hasil yang rendah ini menunjukkan bahwa kelas eksperimen dan kelas kontrol sama-sama belum menguasai materi hidrolisis garam.

Setelah diterapkan model problem based learning pada kelas eksperimen dan metode ceramah pada kelas kontrol, maka dilakukan postest. Nilai postest masing-masing kelas mengalami peningkatan dari pretest karena siswa sudah mempelajari materi yang terkait yaitu hidrolisis garam. Kelas eksperimen memiliki nilai rata-rata postest 83,75 . Nilai rata-rata postest kelas kontrol 79,545. Kelas eksperimen memiliki nilai rata-rata yang lebih tinggi daripada kelas kontrol, sedangkan soal postest yang diberikan adalah sama untuk kelas yaitu 20 soal pilihan ganda materi hidrolisis garam. Berdasarkan nilai postest yang diperoleh oleh siswa, dapat dilihat masih ada siswa yang nilainya berada dibawah KKM, namun secara umum hasil rata-rata nilai postest kelas eksperimen dan kontrol lebih baik daripada nilai pretest.

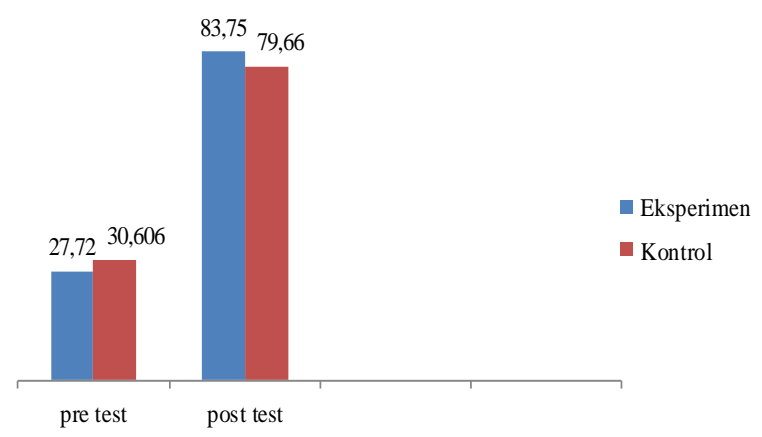

Gambar I. Perbandingan Nilai Pre test dan Post test Kelas Ekperimen dan Kontrol

Nilai rata-rata postest kelas eksperimen setelah dilakukan penerapan model Problem Based Learning terjadi peningkatan, hal ini dikarenakan siswa telah mengetahui tentang hidrolisis garam melalui proses pembelajaran yang 
dilakukan. Pembelajaran dengan menerapkan model ini dilakukan secara berkelompok. Siswa membangun pengetahuannya sendiri untuk memecahkan masalah yang diberikan oleh peneliti. Membangun pengetahuannya sendiri akan mempermudah pemahaman dari siswa tersebut. Selain itu, dengan bekerja sama dengan kelompoknya akan mempermudah siswa dalam menemukan pemahamannya dengan cara bertukar pikiran dengan sesama anggota kelompoknya. Selanjutnya, perwakilan siswa yang ditunjuk oleh guru akan mempresantasikan hasil pemecahan masalah yang didapatkan, dengan demikian setiap siswa harus memahami materi yang dipelajari untuk mempresentasikannya, sehingga akan meningkatkan pemahaman dari siswa tersebut dan menuntut siswa aktif dalam proses pembelajaran. Sedangkan pada kelas kontrol menggunakan pembelajaran ceramah, sehingga pengetahuan yang mereka dapatkan terbatas hanya pada apa yang dijelaskan saja, tidak diberikan kesempatan bagi siswa untuk memperoleh pengetahuan dan membangun pengetahuan bagi diri sendiri.

Dari pengolahan data analisa uji hipotesis, diperoleh nilai thitung 2,55 dan nilai $t_{\text {tabel }} 2,00$. Nilai thitung $>t_{\text {tabel. }}$ Hal ini menunjukan bahwa $\mathrm{H}_{\mathrm{o}}$ ditolak dan $\mathrm{H}_{a}$ diterima. Maka dapat disimpulkan bahwa penerapan model Problem Based Learning berpengaruh terhadaphasil belajar siswa kelas XI pada materi hidrolisis garam dengan besar pengaruh 9,35\%. Penerapan model PBL ini mampu mengatasi permasalahan belajar di SMA Negeri 4 Pekanbaru. Pada tahun sebelumnya sebanyak $54,69 \%$ siswa belum mencapai KKM pada materi hidrolisis garam, sedangkan pada tahun ini hanya $25 \%$ siswa yang belum mencapai KKM untuk kelas eksperimen dan 36,36\% siswa yang belum mencapai KKM pada kelas kontrol. Menurut Ni Made penerapan model pembelajaran berbasis masalah dimaksudkan untuk meningkatkan partisipasi dan prestasi belajar siswa karena melalui pembelajaran ini siswa belajar bagaimana menggunakan konsep dan proses interaksi untuk menilai apa yang mereka kita ketahui, mengidentifikasi apa yang ingin diketahui, mengumpulkan informasi dan secara kolaborasi mengevaluasi berdasarkan data yang telah dikumpulkan [10].

Hasil yang diperoleh menunjukkan bahwa penerapan model problem based learning ini mampu meningkatkan pemahaman siswa. Tahapan - tahanpan PBL ini mampu memberikan pengalaman belajar pada siswa dan dapat membangun kerangka berpikirnya, sehingga indikator pembelajaran dapat tercapai dengan baik. Menurut Sony Hidayat dalam skripsinya dengan judul "Pengaruh Model Pembelajaran Problem Based Learning Terhadap Hasil Belajar Kimia Siswa pada Konsep Termokimia." Penelitian ini menyimpulkan bahwa tes hasil belajar pada kelas eksperimen diperoleh skor rata-rata postest 70,17 dan kelas kontrol dengan rata-rata postest 63,33 . Hasil ini membuktikan bahwa hasil belajar siswa yang diajarkan dengan PBL lebih tinggi dibandingkan dengan siswa yang diajar dengan metode konvenisonal [11]. Selain itu menurut Chin dan Chia model PBL dapat menimbulkan proses kognitif siswa menjadi lebih baik dengan kebiasaan berpikir baik [12]. Hal ini juga dapat dilihat dari nilai LKS kelas eksperimen dan kelas kontrol. nilai LKS kelas eksperimen mengalami peningkatan dari LKS 1 hingga LKS 4, sedangkan LKS kelas kontrol mengalami penurunan pada 
LKS 3. Penurunan nilai LKS kelas kontrol pada pertemuan ketiga ini disebabkan materi yang bersifat hitungan membutuhkan pemahaman yang lebih.

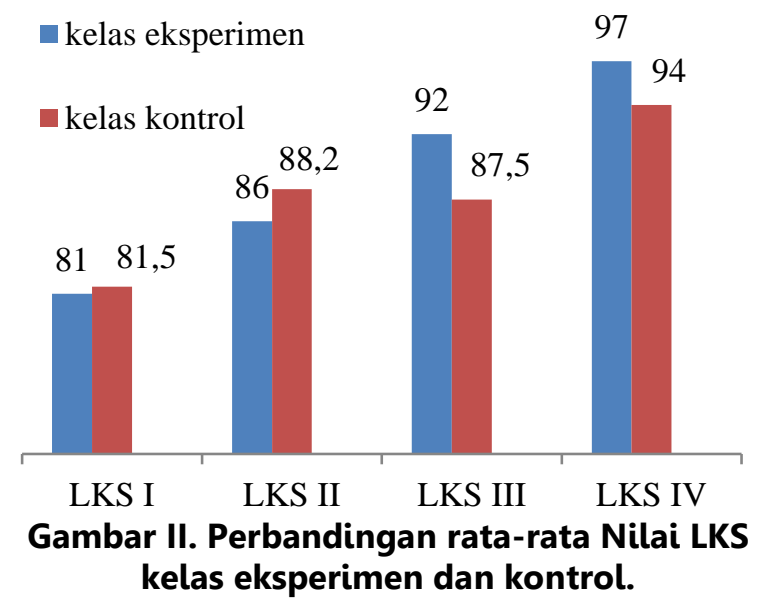

Indikator pembelajaran dapat dicapai dengan baik pada kelas eksperimen karena keunggulan dari model PBL yang diterapkan. Tahapan-tahapan dari model ini mampu mengajarkan siswa bagaimana belajar yang sesungguhnya. Model PBL ini mempunyai lima tahapan, yaitu orientasi siswa pada masalah, mengorganisasi siswa untuk belajar, membimbing penyelidikan siswa, mengembangkan dan menyajikan hasil karya, dan menganalisis dan mengevaluasi proses pemecahan masalah. Kelima tahapan ini mampu memberikan pengalaman belajar dan mengembangkan cara berpikir siswa. Cara berpikir yang tinggi sangat diperlukan untuk memahami materi kimia yang menggabungkan konsep dan perhitungan matematika seperti materi hidrolisis garam. Materi hidrolisis garam merupakan materi yang terdapat konsep aplikatif dalam kehidupan sehari-hari. Materi ini merupakan penggabungan konsep dan perhitungan matematika, sehingga diperlukan cara berfikir dan analisis yang tinggi untuk mengaitkan antara konsep dan perhitungan tersebut.
Dilihat dari tahapannya, model PBL ini memiliki keunggulan pada tahap orientasi siswa pada masalah, penyelidikan siswa, serta menganalisis dan mengevaluasi proses pemecahan masalah. Pada tahap orientasi siswa pada masalah, guru memberikan suatu permasalahan yang berkaitan dengan kehidupan sehari-hari. Permasalahan yang ada dapat membangun keingintahuan dan ketertarikan siswa untuk belajar dan menemukan pemecahan masalah, dengan mengembangkan cara berfikir dari siswa, maka akan meningkatkan pemahaman siswa terhadap materi yang disajikan.

Tahap penyelidikan siswa, siswa bersama kelompoknya berdiskusi saling bertukar pikiran, serta mengumpulkan informasi dari berbagai macam sumber, baik dari buku maupun internet untuk menemukan pemecahan masalah yang ada. Pada tahapan ini siswa belajar bagaimana belajar. Pengetahuan tidak hanya diperoleh dari guru saja, tetapi dapat diperoleh dari segala arah. Dengan melakukan penyelidikan, berarti siswa menemukan sendiri pengetahuannya sehingga akan membangun cara berpikir yang lebih baik. Pengetahuan yang dibangun sendiri akan lebih lama diingat dan akan lebih dipahami siswa, daripada siswa yang hanya menerima pengetahuan dari guru saja.

Tahapan selanjutnya adalah menganalisis dan mengevaluasi proses pemecahan masalah. Pada tahapan ini peneliti akan menunjuk perwakilan kelompok untuk mempresentasikan hasil pemecahan masalah yang telah didiskusikan bersama kelompoknya. Dengan menunjuk secara acak yang mempresentasikan hasil pemecahan masalah, maka setiap siswa harus memahami pemecahan masalah yang telah dibuat oleh kelompoknya. 
Temuan yang ditemukan peneliti pada saat melakukan penelitian ini adalah, praktikum sederhana dapat mendukung model PBL ini dengan baik. Praktikum dapat menunjang kreatifitas dan semangat siswa untuk belajar. Siswa mampu menemukan hal-hal baru yang belum pernah dilakukannya sebelumnya. Siswa tidak hanya sekedar mengetahui teorinya saja tetapi siswa juga ikut menyaksikan secara langsung yang mampu memberikan pengalaman dan kemampuan dari siswa tersebut. Tetapi, model PBL ini kurang efektif digunakan pada materi yang bersifat hitungan seperti menentukan $\mathrm{pH}$ larutan garam yang terhidrolisis. Siswa lebih banyak bertanya kepada guru daripada berdiskusi bersama teman kelompoknya. Materi hitungan sebaiknya menggunakan model atau metode yang dapat diterapkan pada materi hitungan itu sendiri, sehingga akan lebih mempermudah pemahaman dari siswa itu sendiri.

\section{KESIMPULAN DAN SARAN}

Berdasarkan hasil penelitian, dapat disimpulkan bahwa (1) Ada pengaruh penerapan model Problem Based Learning terhadap hasil belajar siswa kelas XI SMA Negeri 4 Pekanbaru pada materi hidrolisis garam.Hal ini dapatdilihat dari nilai thitung $>t_{\text {tabel, }}$ dimana thitung $=2,55$ sedangkan nilai tabel pada taraf signifikan $5 \%=2,00$. Rata-rata nilai postest dari kelas eksperimen adalah 83,75 sedangkan rata-rata nilai postest kelas kontrol adalah 79,545, (2) Pegaruh model Problem Based Learning terhadap hasil belajar siswa kelas XI SMA Negeri 4 Pekanbaru pada pokok bahasan hidrolisis garam pada kelas eksperimen memiliki pengaruh sebesar $9,35 \%$.

Berdasarkan hasil penelitian ini, peneliti memberikan saran yang berhubungan dengan penerapan model Problem Based
Learning, yaitu sebaiknya guru atau peneliti lain yang ingin menerapkan model Problem Based Learning dalam proses pembelajaran kimia harus dipersiapkan semuanya dengan sebaik mungkin agar tidak terdapat kendala waktu pada pertemuan pertama, karena siswa masih belum terbiasa dengan model PBL yang diterapkan. Jika menggunakan praktikum sebaiknya alat dan bahan yang digunakan langsung diletakkan pada setiap kelompok agar tidak menghabiskan banyak waktu.

\section{DAFTAR PUSTAKA}

Kemendikbud. (2013). Permendikbud No. $81 A$ tentang Implementasi Kurikulum. Jakarta: Kementerian Pendidikan dan Kebudayaan.

Sanjaya, W. (2007). Strategi Pembelajaran Berorientasi Standar Proses Pendidikan. Jakarta: Kencana Prenada Media Group.

Diyas, Devi. (2012). Penerapan Model Problem Based Learning untuk Meningkatkan Kemampuan Berpikir Kritis Peserta Didik pada Pembelajaran IPA Kelas VII SMA Negeri 5 Sleman. Skripsi. Fakultas Matematika dan Ilmu Pengetahuan Alam: Universitas Negeri Yogyakarta.
Trianto. (2007). Model-model pembelajaran Inovatif dan berorientasi Konstruktifistik. Jakarta: Prestasi Pustaka Publisher.

Hosnan. (2014). Pendekatan Saintifik dan Kontekstual Dalam Pembelajaran Abad 21 Kunci Sukses Implementasi Kurikulum 2013. Jakarta: Ghalia Indonesia.

Trihatmo, A., Antonius. (2012). Penggunaan ModelProblem Based Learning pada Materi Larutan Penyaangga dan 
Hidrolisis, Semarang, Jurnal FMIPA Kimia Universitas Negeri Semarang, 1(1), 7-13.

Rosidah, R., Redjeki T., Retno S., (2014). Penerapan Model Problem Based Learning (PBL) Pada Pembelajaran Hukum-Hukum Dasar Kimia Ditinjau dari Aktivitas dan Hasil Belajar Siswa Kelas $X$ IPA SMA Negeri 2 Surakarta Tahun Pelajaran 2013/2014, Surakarta, Jurnal Pendidikan Kimia PMIPA, FKIP, UNS Surakarta, Indonesia, 3(3), 66-75.

Sukmadinata. N.S. (2010). Metode Penelitian. Bandung: Remaja Rosdakarya.

Prof. Dr. Sugiyono. (2015). Metode Penelitian Kombinasi (Mixed Methods). Bandung: Alfabeta.
Suci, N.M. (2008). Penerapan Model Problem Based Learning Untuk Meningkatkan Partisipasi Belajar dan Hasil Belajar Teori Akuntansi Mahasiswa Jurusan Ekonomi Undiksha. Universitas Pendidikan Ganesha,2(1), 74-86.

Hidayat, M.(2011). Pengaruh Model Pembelajaran Problem Based Learning Terhadap Hasil Belajar Kimia Siswa pada Konsep Termokimia.Skripsi. Fakultas Tarbiyah dan Keguruan: UIN Syarif Hidayatullah Jakarta.

Chin C., dan Cina, L. (2005). Problem Based Learning. Using IIIStructured Problems in Biology Project Work, Wiley Interscience. 